\title{
ATIVO INTANGíVEL E VALOR DE MERCADO: EVIDÊNCIAS DA RELAÇÃO ENTRE EMPRESAS BRASILEIRAS DE CAPITAL ABERTO
}

\section{Pedro, Débora L.}

\section{Resumo}

A criação de valor de mercado para uma empresa está, muitas vezes, intrinsecamente relacionada com seus ativos intangíveis. A análise de tal correlação é de grande importância na gestão dos ativos e passivos da companhia, auxiliando na busca pela maximização do valor. Neste contexto, o objetivo desta iniciação científica é avaliar a relação entre ativo intangível, representado pelo Grau de Intangibilidade, e valor de mercado das empresas brasileiras de capital aberto no período de 2010 a 2015, considerando variáveis de controle baseadas em informações econômicofinanceiras das companhias. Após realizadas as devidas análises, utilizando métodos econométricos com base em regressões múltiplas e dados em painel, observou-se que o Grau de Intangibilidade (GI) de fato influencia a rentabilidade e o valor de mercado das empresas. Ou seja, quanto maiores os gastos com incrementos em intangíveis, maior será o retorno e, portanto, mais atrativa será a companhia para os shareholders.

Palavras-chave: Ativo intangível, criação de valor, capital intelectual.

\section{Introdução}

A tecnologia e o conhecimento incorporados no produto são fatores que têm diferenciado as empresas. Os ativos intangíveis - capazes de gerar benefícios futuros sem possuir equivalente físico ou financeiro, como Pesquisa e Desenvolvimento, marcas e softwares - são cada vez mais presentes e importantes na composição do ativo e, consequentemente, do valor de uma empresa.

A criação de valor para as empresas, resultado das decisões operacionais, de investimento e financiamento, é de extrema importância para o seu fortalecimento frente aos concorrentes. Vale observar que este valor pode ser mensurado, pelo menos, de três maneiras: valor contábil, valor intrínseco e valor de mercado.

Assim sendo, o presente estudo tem o objetivo de avaliar a relação entre valor de mercado das empresas e seu ativo intangível.

\section{Resultados e Discussão}

A amostra compreende 164 companhias brasileiras não financeiras listadas na BM\&FBOVESPA entre 2010 e 2015. Os dados utilizados foram extraídos das demonstrações contábeis por meio do software Economática.

Com base nos métodos de Mínimos Quadrados Ordinários (MQO) e Efeitos Fixos, elaborou-se um modelo cuja variável dependente é uma proxy do valor da empresa (Ebitda/Ativo). Entre as variáveis explicativas, além de uma variável relativa ao ativo intangível, foi incluído um grupo de variáveis de controle, conforme equação a seguir:

Ebitda/ativo $=\beta_{0}+\beta_{1} G_{i}+\beta_{2}$.iro $_{i}+\beta_{3}$ divativo $_{i}$

$+\beta_{4}$ ROE $_{i}+\beta_{5}$ qualdiv $_{i}+\beta_{6}$ lnativo $_{i}$

$+\varepsilon_{i}$

A tabela abaixo mostra os resultados do modelo estimado pelo método de efeitos fixos (eleito como o mais adequado após realizado o teste de Hausman):

\begin{tabular}{lccc}
\hline & Coef. & $\mathrm{t}$ & $\mathrm{P}>\mathrm{t}$ \\
\hline ROE & 0,00013 & 2,62000 & 0,00900 \\
Giro & 0,00033 & 3,24000 & 0,00100 \\
\hline
\end{tabular}

DOI: 10.19146/pibic-2016-51014

\begin{tabular}{llll}
\hline Gl & 0,00968 & 2,07000 & 0,04000 \\
Dívida/Ativo & $-0,00163$ & $-3,19000$ & 0,00200 \\
QualDív & $-0,00012$ & $-0,67000$ & 0,50300 \\
Ln(ativo) & 0,03015 & 1,51000 & 0,13400 \\
2011 & $-0,00413$ & $-0,57000$ & 0,56600 \\
2012 & $-0,01662$ & $-2,17000$ & 0,03100 \\
2013 & $-0,02337$ & $-1,58000$ & 0,11600 \\
2014 & $-0,02307$ & $-1,97000$ & 0,05100 \\
2015 & $-0,03500$ & $-2,52000$ & 0,01300 \\
Cons & $-0,30346$ & $-1,04000$ & 0,30100 \\
\hline
\end{tabular}

As variáveis retorno sobre o patrimônio líquido $(R O E)$, giro do ativo (Giro) e o grau de intangibilidade (GI) são positivamente correlacionadas com a rentabilidade das empresas e, consequentemente, com o seu valor de mercado. Por outro lado, foram encontradas evidências de que o aumento do endividamento (Dívida/Ativo) reduz o valor das corporações.

\section{Conclusões}

Por meio da pesquisa e análises realizadas, pode-se concluir que o Grau de Intangibilidade (GI) de fato influencia a rentabilidade e o valor de mercado das empresas. Todavia, tal relação é diminuta, o que pode ser explicado pela composição do GI, a qual considera os valores contábil e de mercado de uma empresa, sendo, portanto, influenciada por fatores externos à atividade operacional - que se refletem no preço de suas ações e, consequentemente, em seu valor de mercado. Outro fator que contribui para a baixa expressividade do Gl é a falta de variáveis que expressem, de maneira mais direta, o investimento das empresas em ativos intangíveis, tais como o investimento em P\&D e o número de depósito de patentes.

Observa-se, portanto, que quanto maiores os gastos realizados com incrementos em intangíveis, maior o retorno e, portanto, mais atrativa será a companhia para os shareholders. 